\title{
The Great Steppe Frontier of Ukraine as A Contributing Factor to the Formation of the Cossack Raids in the $16^{\text {th }}$ and $17^{\text {th }}$ Centuries
}

\author{
Oksana Amelina'
}

'Corresponding author/Sorumlu yazar: Oksana Amelina (Post graduate student), I. I. Mechnikov Odessa National University, Faculty of History and Philosophy, Department of History of Ukraine, Odessa, Ukraine.

E-posta: sunkiss2017@ukr.net ORCID: 0000-0002-2450-7848

Submitted/Başvuru: 13.09.2020 Revision Requested/Revizyon Talebi: 13.11.2020

Last Revision Received/Son Revizyon:

15.11.2020

Accepted/Kabul: 20.12.2020

Citation/Atıf: Amelina, Oksana, “The Great Steppe Frontier of Ukraine as A Contributing Factor to the Formation of the Cossack Raids in the $16^{\text {th }}$ and $17^{\text {th }}$ Centuries", Güneydoğu Avrupa Araştırmaları Dergisi, 35 (2020), s. 9-16. https://doi.org/10.26650/gaad.794451

\begin{abstract}
The article considers the influence of the Great Steppe Frontier of Ukraine substantiating that the influence of the Great Steppe Frontier of Ukraine was not a line of demarcation between West and East, nor between other aspects of human life. The result was the emergence of a frontier way of life that included local traditions and borrowed elements of other cultures. In early modern European history, the Ukrainian Frontier witnessed the political rise of the Ukrainian Cossacks. One of the manifestations of the Cossacks' frontier life of was the tradition of prey - traditional Cossack activities aimed at collecting booty, mainly in border struggles and skirmishes with the Turks, Tatars, Nogai.

The article also contains a brief analysis of historiography on the issue. It studies the formative period of Cossack raids in search of spoils. The article offers an analysis of the components of Cossack raiding activity in the studied period and hints at the influence of these activities on the Steppe Frontier of Ukraine It also emphasizes the geographical and chronological boundaries of the Great Ukrainian Steppe Frontier and their impact on the border life of Ukrainian Cossacks.
\end{abstract}

Keywords: Cossack Raiding, Ukrainian Steppe Frontier, "Cossack Bread", Socio-Cultural Interaction 
In the $16^{\text {th }}$ and the first half of the 17 th century was laid the foundations of domestic and military Cossack culture and the worldview attached to it. This period became a turning point in the socio-cultural transformation of the Ukrainian Cossacks in which not only a notion of frontier understanding formed but also several ideas emerged that influenced subsequent historical research. Therefore, it is not surprising that the Ukrainian Cossacks appeared in the pages of national history as the "chivalry" of the steppe frontier. Historical studies commonly underlined the fact that the Ukrainian lands were protected by the Cossacks from Turkish-Tatar attacks. However, the Cossack campaigns against the Turks, Tatars, and Nogai have not been the focus of historians. Only in recent decades, have researchers begun to discuss the Cossack campaigns against Turkic societies and their impact on the socio-cultural features of the Ukrainian Cossacks. As V. Brekhunenko remarked: "At the turn of the 20th-21st centuries the problem of the consequences of Cossack campaigns in Turkey and the Crimea was fruitfully conceptualized"'. In Western European and domestic historiography, this trend has become relevant in the context of studying the influence of the Great Steppe Frontier, which passed through the territory of Ukraine in the eighteenth century. Mining became one of the components of the Cossack military interaction with the Turkic world, which was reflected in all the specifics of the Cossacks' frontier way of life.

Historiography on this issue includes works both by domestic and foreign researchers and historians. It is true that, since the late $19^{\text {th }}$ and early 20 th century historians and researchers have begun to focus on the influence of the Great Steppe Frontier on the military culture of the Ukrainian Cossacks. M. Hrushevsky was one of the first to note in his multi-volume work "History of Ukraine-Russia" the influence of the Ukrainian border between the West and the East on the peculiar, specific economic activity and the culture of the Cossacks, as well as the formation of the tradition of Cossack raiding ${ }^{2}$. The research of the Soviet scholars V. Holobutsky, V. Dovnar-Zapolsky, 0. Apanovych, and I. Krypyakevych is quite fundamental in studying the subject of Cossack raiding within the Ukrainian Frontier, since the topic was "banned" in Soviet times. It is worth noting that the works of I. Lysyak-Rudnytsky also focused on the issue of the cross-border lifestyle of Ukrainians. The topic drew special attention during the years of Ukraine independence: J.Dashkevych, S. Lepyavka, V. Hrybovsky and V. Brekhunenko, all examined the problem of Cossack-Tatar cooperation in the context of the Great Steppe Frontier.

It should be noted that in the works of Alan Fischer, Frederick Turner, and Maria Barmava, various aspects of the Steppe Frontier are mentioned as historical research areas, including the Ukrainian aspect. Without going into theoretical and methodological discussions on the interpretation of the concept of "borders" and "frontiers", it is sufficing to note that

1 Brekhunenko V. Cossack yasir and trade in it in the XVI- first half of the XVII century. / V. Brekhnenko // History of trade, taxes and duties. - 2010. - № 1. - C.96.

2 Hrushevsky M. History of Ukraine-Rus / M. Hrushevsky. - T. VII. - K .: Naukova dumka, 1995. - 624 c. 
the concept of "Great Frontiers", which run across the globe and create specific conditions for the existence and development of nationalities in their territories, is not new. However, it has mostly been developed and researched by American scholars. In particular, the main ideologue of this concept - F. Turner - noted: "Much has been written about the frontier from the point of view of border warfare and the chase, but as a field for the serious study of the economist and the historian it has been neglected"3. In this statement, he emphasizes the importance of the border or frontier not only as a line of demarcation on the map or terrain, but also as a zone of interaction of two different cultures, a zone that provides the basis for a new frontier way of life.

This thesis can be applied to the study of the national frontiers. The main idea of the Ukrainian Steppe Frontier is that the border zone between two very different ethnic and cultural worlds of East and West passes through the territory of the Ukrainian state. In this zone of interaction of the two worlds, a third completely new element of culture is formed, the features of which are not inherent in either of the two interacting ones.

It is worth noting that the large American and European (of which the Ukrainian border was a part) borders had a significant difference. In the case of the American Great Frontier, the European side's advantage was damaging and threatening to the local population, while the European Great Frontier was a zone of confrontation between two equal forces, leading to the swaying and dominance of one side or the other ${ }^{4}$. As a result, there was border mobility. Therefore, contemporaries characterize the Ukrainian Steppe Border as a Frontier - a mobile zone of interaction of different cultures.

I. Lysyak-Rudnytsky was one of the first to transfer the theory of the Great Frontier to the territory of Ukrainian history and noted that in methodological terms the use of this theory, especially in the study of Cossacks, was quite appropriate. Transferring the theories of American scholars to Ukraine, Lysyak-Rudnytsky noted that “... the Ukrainian man of the frontier was a Cossack... In essence, the Cossacks were an organization of military self-defense of the endangered frontier lands... it also borrowed many tactical tools and customs from its Tatar enemies". ${ }^{5}$

Ukrainian Steppe Frontiers existed until the 18th century and depended on the militar$y$-political interaction between the Grand Duchy of Lithuania, and later the Polish-Lithuanian Commonwealth and the Ottoman Empire and its vassal, the Crimean Khanate and the Nogai hordes, and became the territory of the formation of the Ukrainian Cossacks. According to the

3 Frederick J. Turner The Significance of the Frontier in American History (1894) [Digital resource] // Access mode: https://www.historians.org/about-aha-and-membership/aha-history-and-archives/archives/the-significanceof-the-frontier-in-american-history (06.03.2020).

4 Dashkevych J. Cossacks on the Great Border / J. Dashkevych // Ukrainian Historical Journal. - K., 1990. - № 12. - P. 20.

5 Lysyak-Rudnytsky I. Ukraine between East and West / I. Lysyak-Rudnytsky. - Kyiv: PJSC “Ukrainian Press Group", 2012. - P. 13-14. 
Ukrainian historian V. Brekhunenko, the "classical" or "heroic" era of the Ukrainian Cossacks took place on the Frontier in the $16^{\text {th }}$ and 17 th centuries, because this period was key in the institutionalization, formation of their own Cossack identities and representations in the world 6 .

Natural or politico-cultural boundaries that are formed during the historical development of mankind have zones of conflicts. Sociocultural phenomena are also formed in the border areas, which are the result of the interaction of different cultures and worldviews which are opposed to each other ${ }^{7}$. Thus, the Ukrainian Cossacks as a phenomenon of contemporary Europe were formed within the Great Steppe Frontier, and directly influenced the peculiarities of Cossack culture, and at the same time, the formation and booty collecting as one of elements of the military culture of the Cossacks.

The main form of raiding was the border clashes of the Cossacks against the Turks and Tatars, the main purpose of which was to capture the prey ${ }^{8}$. However, spoils, like the Cossacks themselves, went through stages of formation, becoming and transformation. It brought not only material benefits, but also reflected the border type of life, thinking, culture, which in turn combined the socio-cultural elements of East and West.

Using methodological principles, our contemporaries highlight the boundaries of the steppe of Ukraine Frontier. Between the $16^{\text {th }}$ and18th centuries the northern Black Sea coast was the centre of the Great Frontier, a clearly blurred boundary between the agricultural and nomadic worlds, which periodically shifted from the forest-steppe strip to the steppe boundary and gravitated toward the Black Sea coast itself. Its obvious vagueness, width of hundreds of kilometers, and in the political sense, its amorphous quality and lack of clear documentary definition are the characteristics which do not allow us to compare the marked border with any other borders of the late Middle Ages and early modern times?.

It should be noted that despite the concentration of the Steppe Frontier in the Black Sea steppes, it stretches to "a vast expanse of steppe and forest space, focused through a system of forested, the Black, Azov and Caspian Seas and open to invasions from both the East and the north". ${ }^{10}$ Therefore, the Ukrainian Steppe Frontier was part of the Great Frontier, which stretches "... from the Dniester to the Volga and Yaik."11

6 Brekhunenko V. Cossacks on the Steppe Border of Europe. Typology of Cossack communities of the XVI- first half of the XVII century. / V. Brekhnenko - K., 2011. - P. 11.

7 Barmova M. Europe, the Danube and the Ottomans (1396 - 1541). - University Publishing House "St. Clement of Ohrid “. - Sofia, 2014. - P. 27.

8 Pletsky SF Mining. - Ukrainian Cossacks: Small Encyclopedia. - Kyiv: Genesis; Zaporozhye: Premier, 2002. - P. 172.

9 Hrybovsky V. Zaporozhye-Nogai borderland in the XVI-XVIII centuries / V. Hrybovsky. [Electronic resource]. Access mode: http://www.cossackdom.com/articles/g/gribovskyi_zaporozhpobuzh02081.htm (20.02.2020).

10 Brekhunenko V. Cossacks on the Steppe Border of Europe. Typology of Cossack communities of the XVI- first half of the XVII century. / V. Brekhnenko - K., 2011. - P. 24.

11 Brekhunenko V. Cossacks on the Steppe Border of Europe. Typology of Cossack communities of the XVI- first half of the XVII century. / V. Brekhnenko - K., 2011. - P. 26. 
Each region of the Great Steppe Frontier had its own civilizational factor, which influenced the ethno-cultural features of the local population. In the region of the Great Steppe Frontier, as noted above, which was concentrated in the Black Sea steppes, a special factor was the Cossack-Tatar-Nogai interaction. The inhabitants of the steppe frontier, whether on one side or the other, became the first subjects of interaction. Therefore, in the cultural and later ideological aspects of Cossack life, we can trace a kind of symbiosis of two civilizations - nomadic and settled worlds - which actually resulted in the phenomenon of Cossack raiding.

It should be noted that the Ukrainian Frontier was an unstable, mobile zone of interaction not only of socio-cultural aspects, but also of geopolitical interests. Thus, these territories were of interest to the Crimean Khanate (which was a vassal of the Ottoman Empire), the Polish-Lithuanian state, as well as the Moscow principality. ${ }^{12}$ Therefore, the Ukrainian Frontier was mobile and changed its borders in accordance with military and political circumstances.

Based on the above, we can talk about certain parallels between the Tatar yasir and Cossack booty ${ }^{13}$. Whereas the Tatars based their military hunting on horses and human captives, the Cossacks in the 16th century concentrated on sheep, oxen and cattle. This was due to the fact that the animals could be used on their own farms or sold in the markets to locals. In the Black Sea region, the Crimean Tatars were engaged in cattle grazing and sheep breeding. Therefore, sheep herds were the single most captured items in the region. In 1516, for instance, the Cossacks in the vicinity of Belgorod and Ochakovo attacked shepherds and took about a thousand sheep ${ }^{14}$. According to reports from the Polish guard Stanislaw Gulski to the Polish king from December 1582, the Cossacks from Pryluky and Nemyriv took several thousand sheep from the Turks ${ }^{15}$.

In the second half of the 16th century the Ukrainian Cossacks were institutionalized in Zaporizhzhya Sich and the registered Cossacks - this directly influenced on the transformation of Cossack production and the emergence of such a concept as "Cossack bread" - which included not only economic benefits but also ideological justification.

During this period, a certain Cossack ideology and an individual worldview began to emerge in the Sich environment, and as a result, the attitude to raiding changed. These moments are reflected in this action of Cossacks taking captives as booty. Whereas at the end of the 15th century human captivity was not entirely acceptable to the Cossack battalions, and the sources mentioned only isolated cases of enslaved people in order to obtain ransom

12 Fisher Alan. The Crimean Tatar Khanate. Stanford University. - 1978. Stanford, P.13, 41.

13 Hrybovsky V. Zaporozhye-Nogai borderland in the XVI-XVIII centuries / V. Hrybovsky. [Electronic resource]. Access mode: http://www.cossackdom.com/articles/g/gribovskyi_zaporozhpobuzh02081.htm (20.02.2020).

14 Cherkasy B. Ukrainian Cossacks in the late XV - in the first half of the XVI century. / B. Cherkasy // History of the Ukrainian Cossacks: Essays in two volumes / Resp. ed. Smoliy V. A. - Kyiv: Publishing House "Kyiv-Mohyla Academy", 2006. - Vol. 1. -P. 57.

15 Lepyavko S. Cossacks and Tatars in the early 1580s / S. Lepyavko // Scientific notes. Collection of works of scientists and graduate students. - T. 6. - K., 2001. - P. 30. 
for them, from the middle of the 16 th century onwards we encounter more and more complaints from the Crimean khan and the Turkish sultan about the Cossacks' capture of the local people. One of the factors that influenced such changes was purely psychological and moral. The Cossacks, who had entered the stage of their institutionalization and begun to take shape in a kind of military-political organization, turned to human booty to create the possibility of exchanging these prisoners with their fellow Cossacks and the local non-Muslim population which the Tatars took during skirmishes or raids on the territories of modern Ukraine. However, the leading place was occupied by economic aspects of Cossack mining.

According to P. Sass, in the late $16^{\text {th }}$ and the first half of the 17 th century the Ukrainian Cossacks perceived themselves as knights, that is, personally free people, whose way of life was determined by military craft and belonging to a separate, usually enclosed military community ${ }^{16}$. According to scholars, the main knightly virtues that were inherent in the Cossack environment included: courage, bravery, loyalty, dignity, honor, ability to self-sacrifice, and service to high ideals ${ }^{17}$. The latter had ideological features, which were directly influenced by the positioning of the Cossacks themselves as defenders of the Orthodox faith against the Muslim threat.

Sources allow us to claim that the Cossacks called themselves "knightly people"18. As noted in the letters of the Cossack hetmans to the Polish king: "to us, as people of chivalry..."19, or "all chivalry", "all chivalry of Zaporozhye..." 20 .

Obviously, one of the factors in the transformation of raiding was religious. From the very beginning, the Cossacks have constantly opposed the Turkish-Tatar forces of Muslim faith who considered it their duty to wage a "Holy War" against infidel Christians ${ }^{21}$. In the process of forming their own identity and worldview, the Cossacks placed themselves as the main defender of the Christian world against Muslim aggression, a fact that allowed Ukrainian knights to wage a kind of holy war against Turkish-Tatar incursions.

16 Sas P. Military fishing of the Zaporozhian Cossacks (first half of the XVII century) / P. Sas // Ukraine in Central and Eastern Europe (from ancient times to the end of the XVIII century). - Kyiv: Institute of History of Ukraine, National Academy of Sciences of Ukraine, 2007. - Issue. 7. - P.187.

17 Sas P. Military fishing of the Zaporozhian Cossacks (first half of the XVII century) / P. Sas // Ukraine in Central and Eastern Europe (from ancient times to the end of the XVIII century). - Kyiv: Institute of History of Ukraine, National Academy of Sciences of Ukraine, 2007. - Issue. 7. - P.178.

18 Letter of Hetman of the Zaporozhian Army Kryshtof Kosynsky to the King of the Commonwealth Zygmunt III, September 1592 (Document № 20) // Documents of the Ukrainian Cossacks of the XVI- first half of the XVII century: universals, correspondence, agreements, oaths / Emphasis. V. Brekhunenko. - K., 2016. - P. 58-60.

19 Letter of the Senior Zaporozhian Army Hryhoriy Loboda to the Grand Crown Hetman Jan Zamoysky, January 1596 (Document № 42) // Documents of the Ukrainian Cossacks of the 16th - first half of the 17th centuries: universals, correspondence, agreements, oaths / Emphasis. V. Brekhunenko. - K., 2016. - P. 89-90.

20 Letter of the senior army of Zaporizhia Prokop Sarapovych to the King of the Commonwealth Zygmunt III, March 1600 (Document № 61) // Documents of the Ukrainian Cossacks of the XVIth and first half of the XVIIth century: universals, correspondence, agreements, oaths / Emphasis. V. Brekhunenko. - K., 2016. - P. 106-108.

21 Chukhlib T. Cossacks and Janissaries: Ukraine in the Christian-Muslim wars of $1500-1700$ years / T. Chukhlib. - Smoliy V.A. - Kyiv: Publishing House "Kyiv-Mohyla Academy", 2010. - P. 43-44. 
In short, the Great Ukrainian Steppe Frontier had its own geographical and chronological boundaries. The zone of concentration of the steppe border, and as a consequence, the zone of interaction for the $16^{\text {th }}$ and17th centuries became the Black Sea steppes. The Frontier did not act as a barrier. First of all, it was a zone of socio-cultural and military interaction, the result of which - the formation and becoming of the Ukrainian Cossacks - was a separate state of the military border population, "border knights." One of the aspects of the frontier way of life was the Cossack raiding. In fact, Cossack troops copied booty collecting practices from the Turkic peoples, but under the influence of their own traditions, it acquired a number of sociocultural features and became a phenomenon of the Ukrainian Cossacks.

\footnotetext{
Hakem Değerlendirmesi: Dış bağımsız.

Çıkar Çatışması: Yazar çıkar çatışması bildirmemiştir.

Finansal Destek: Yazar bu çalışma için finansal destek almadığını beyan etmiştir.
}

Peer-review: Externally peer-reviewed.

Conflict of Interest: The author has no conflict of interest to declare.

Grant Support: The author declared that this study has received no financial support.

\section{Bibliography}

Barmova M. Europe, the Danube and the Ottomans (1396 - 1541). - University Publishing House "St. Clement of Ohrid “. - Sofia, 2014.

Brekhunenko V. Cossack yasir and trade in it in the XVI XVI- first half of the XVII century. / V. Brekhnenko // History of trade, taxes and duties. - 2010. - № 1.

Brekhunenko V. Cossacks on the Steppe Border of Europe. Typology of Cossack communities of the XVI XVI- first half of the XVII century. / V. Brekhnenko - K., 2011.

Cherkasy B. Ukrainian Cossacks in the late XV - in the first half of the XVI XVI century. / B. Cherkasy // History of the Ukrainian Cossacks: Essays in two volumes. - Kyiv: Publishing House "Kyiv-Mohyla Academy", 2006. - Vol. 1.

Chukhlib T. Cossacks and Janissaries: Ukraine in the Christian-Muslim wars of $1500-1700$ years / T. Chukhlib. - Kyiv: Kyiv-Mohyla Academy Publishing House, 2010.

Dashkevych J. Cossacks on the Great Border / J. Dashkevych // Ukrainian Historical Journal. - Kyiv, 1990. - № 12.

Documents of the Ukrainian Cossacks of the XVI XVI- first half of the XVII century: universals, correspondence, agreements, oaths / Emphasis. V. Brekhunenko. - K., 2016.

Fisher Alan. The Crimean Tatar Khanate. Stanford: Stanford University. - 1978.

Frederick J. Turner The Significance of the Frontier in American History (1894) [electronic resource]. Access mode: https://www.historians.org/about-aha-and-membership/aha-history-and-archives/ archives/the-significance-of-the-frontier-in-american-history (06.03. 2020).

Hrushevsky M. History of Ukraine-Rus / M. Hrushevsky. - T. VII. - Kyiv: Scientific Opinion, 1995.

Hrybovsky V. Zaporizhzhya-Nogai frontier in the 16th - 18th centuries / V. Hrybovsky. [Electronic resource].

- Access mode: http://www.cossackdom.com/articles/g/gribovskyi_zaporozhpobuzh02081.htm (20.02.2020). 
Lepyavko S. Cossacks and Tatars in the early 1580s / S. Lepyavko // Scientific notes. Collection of works of scientists and graduate students. - T. 6. - K., 2001.

Lysyak-Rudnytsky I. Ukraine between East and West / I. Lysyak-Rudnytsky. - Kyiv: PJSC “Ukrainian Press Group", 2012.

Pletsky SF Mining. - Ukrainian Cossacks: Small Encyclopedia. - Kyiv: Genesis; Zaporozhye: Premier, 2002.

Sas P. Military fishing of the Zaporozhian Cossacks (first half of the XVII century) / P. Sas // Ukraine in Central and Eastern Europe (from ancient times to the end of the XVIII century). - Kyiv: Institute of History of Ukraine, National Academy of Sciences of Ukraine, 2007. - Issue. 7. 